\title{
World at work: Fish processing workers
}

\section{F Jeebhay, T G Robins, A L Lopata}

\section{Spotlight on a growth industry}

T he fishing and fish processing industry has experienced tremendous growth in recent years. In 1990 the Food and Agriculture Organisation (FAO) estimated that the number of people engaged in fishing, aquaculture, and related activities worldwide doubled to 28.5 million from 1970 . Among these workers 52\% worked aboard fishing trawlers, 32\% were involved in aquaculture production (marine and freshwater), and 16\% worked inland as capture fishers or in other land based activities such as processing. Ninety five per cent of these workers were from developing countries, producing $58 \%$ of the 98 million tons of world fish. Increased levels of production and processing of seafood have led and continue to lead to more frequent reporting of occupational health problems such as asthma among fish processing workers. ${ }^{2}$ These occupational health problems result in increased incapacity and absenteeism among affected workers, with women more affected as a result of differences in physical exposures and psychosocial work environments. ${ }^{3}{ }^{4}$

\section{THE FISHING INDUSTRY IN SOUTH AFRICA}

The fishing industry in South Africa employs approximately 30000 workers in direct employment in more than 100 workplaces and 60000 workers in related jobs, supplying food for the entire Southern African sub-region. Labour in this industry tends to be divided along gender lines, with men almost exclusively going out to sea to catch the fish and women doing the majority of on-land processing. A large proportion $(62 \%)$ of the workforce in fish processing plants is female and at least one third of the workforce is employed on a seasonal basis by the industry. In 1999, the total harvest of seafood amounted to 571924 tons, among which bony fish such as anchovy, hake, and pilchard are the most common seafood processed. This was confirmed in a recent postal survey in which $76 \%$ of all seafood processing workplaces processed bony fish. ${ }^{5}$

\section{FISH PROCESSING WORK ENVIRONMENT \\ Work processes, job tasks, and working practices}

Fish processing plants in South Africa, as in other parts of the world, vary in technology levels, with smaller workplaces relying entirely on manual handling of fish and larger companies using modern highly automated processes. Various processing techniques are used and include heading, degutting, skinning, mincing, filleting, trimming, cooking (boiling or steaming), spice/batter application, frying, fishmeal milling, and bagging. A study of South African workplaces indicated that freezing $(71 \%)$, cutting $(63 \%)$, and degutting $(58 \%)$ ranked the most common. ${ }^{5}$ Among the finfish, hake (filleted, fried, spice/batter applied), pilchard (canned), and anchovy (minced into paste and fishmeal production) were commonly processed (table 1).

\section{Workplace hazards and high risk work}

The health problems among fish processing workers have been attributed mainly to safety risks (mechanical and electrical accidents); excessive noise levels and low temperatures; bacterial and parasitic infections; bioaerosols containing seafood allergens, microorganisms, and toxins; and poor ergonomic practices and workplace organisation. These commonly result in fatal or non-fatal injuries and occupational diseases such as frostbite and aggravation of Raynaud's phenomenon; ${ }^{6}$ noise induced hearing loss; ${ }^{3}$ skin infection and sepsis; ${ }^{7}$ allergic respiratory diseases (rhinoconjunctivitis, asthma, extrinsic allergic alveolitis) and skin conditions (urticaria, contact dermatitis $) ;^{28}$ musculoskeletal cumulative trauma disorders; ${ }^{10}$ and stress related health problems ${ }^{3}$ (table 2 ). The reported prevalence of occupational asthma associated with fish processing is $2-8 \%$, and occupational protein contact dermatitis (PCD) and urticaria is $3-11 \%{ }^{2}$ Musculoskeletal disorders of the neck and shoulders occur in $31-35 \%$ of the workforce, with younger untrained or unskilled women being more adversely affected. The prevalence of epicondylitis and carpel tunnel syndrome is much lower $(15 \%) .^{910}$

The adverse non-immune (toxic) and immune (allergic) reactions to seafood are the result of exposure to the seafood itself (muscle and connective tissue, exoskeleton, blood, endolymph fish juice, skin, skin slime/mucin, entrails) or to various non-seafood components present in the product (table 2). ${ }^{2}$

Aerosolisation of the seafood during processing has been identified as a potential high risk activity for immunological sensitisation by high molecular weight proteins, respiratory symptoms, non-specific bronchial hyperresponsiveness, and work related asthma. ${ }^{211} 12$ Processes include degutting, heading, and cooking/boiling of fish, mincing of seafood, fishmeal milling/bagging, and cleaning of the processing line and storage tanks with high pressured water (table 1). ${ }^{2}$ Despite high levels of automation in larger workplaces, workers may still be at high risk of developing health problems due to inadequate and poorly designed local exhaust ventilation systems (figs 1-2). ${ }^{11}$ There is great variability of exposure to bioaerosols with allergen concentrations ranging from $2 \mathrm{ng} / \mathrm{m}^{3}$ in a fish market to $1000 \mathrm{ng} / \mathrm{m}^{3}$ in a salmon processing plant. ${ }^{211} 12$ Wet processing activities (grading, gutting, packing fish, automated gutting machine) in salmon filleting plants appear to produce higher particulate (respirable fraction) concentrations than dry activities (fish butchery, packing in cold store and box store). ${ }^{11}$ Consistently high mean fish antigen concentrations (thoracic fraction) have been detected in fishmeal loading and bagging activities $\left(>100 \mathrm{ng} / \mathrm{m}^{3}\right)$ compared to fish canning activities in South African workplaces processing anchovy and pilchard fish respectively. Fishmeal operations also produced consistently increased levels of endotoxin (>50 endotoxin units (EU)/ $\mathrm{m}^{3}$ or $\left.\sim 5 \mathrm{ng} / \mathrm{m}^{3}\right)$. While no threshold limit values currently exist for exposure to fish or other seafood allergens, a level of $50 \mathrm{EU} / \mathrm{m}^{3}$ has been proposed for endotoxin related health effects. ${ }^{13}$

Occupational dermal exposure occurs mainly as a result of unprotected handling of various fish and their products at various stages in the production process (table 2; fig 3). Fish juice contains high molecular weight proteins, biogenic amines, histamine and cadaverine, degradation compounds in old fish, and digestive enzymes (pepsin and trypsin). ${ }^{28}$ The major skin manifestations associated with exposure are contact urticaria and eczematous contact dermatitis of various types. Contact with 
Table 1 Commonly observed production activities and sources of occupational exposure to seafood products in the fish processing industry of the Western Cape province of South Africa

\begin{tabular}{|c|c|c|c|}
\hline $\begin{array}{l}\text { Production } \\
\text { activity }\end{array}$ & Main fish type & Description of processing steps & $\begin{array}{l}\text { Sources of occupational exposure to } \\
\text { seafood product(s) }\end{array}$ \\
\hline Fish canning & $\begin{array}{l}\text { Pilchard } \\
\text { (Sardinops ocellata) }\end{array}$ & $\begin{array}{l}\text { - Fish pumped from holding tanks to sorting tables } \\
\text { - Fish hooked and aligned manually on conveyor belt } \\
\text { - Moves through autopacker for decapitation and degutting } \\
\text { - Steamed in exhaust box oven } \\
\text { - Trainer removes excess water by tipping cans } \\
\text { - Tomato based sauce and spices added } \\
\text { - Cans sealed, autoclaved, labelled, and packaged }\end{array}$ & $\begin{array}{l}\text { - Inhalation of wet aerosols during } \\
\text { degutting and cooking/boiling } \\
\text { - Skin contact from unprotected handling } \\
\text { of various fish and fish juice }\end{array}$ \\
\hline Fish filleting & $\begin{array}{l}\text { Hake } \\
\text { (Merluccius capensis, } \\
\text { M paradoxus) }\end{array}$ & $\begin{array}{l}\text { Small plants: mainly manual cutting and degutting } \\
\text { - Large plants: fully automated machines performing degutting, } \\
\text { heading, skinning, filleting, grading, and trimming to specific sizes } \\
\text { - Cryogenic technology used to freeze fish fillet } \\
\text { - Phosphates added when frozen and stored }\end{array}$ & $\begin{array}{l}\text { Inhalation of wet aerosols } \\
\text { during degutting and } \\
\text { heading } \\
\text { - Skin contact from unprotected handling } \\
\text { of various fish and fish juice }\end{array}$ \\
\hline $\begin{array}{l}\text { Fishmeal } \\
\text { production }\end{array}$ & $\begin{array}{l}\text { Anchovy } \\
\text { (Engraulis capensis) } \\
\text { Pilchard offal }\end{array}$ & $\begin{array}{l}\text { - Fish stored in pits, formalin added to stabilise fish } \\
\text { - Fish transferred from pits by hoppers } \\
\text { - Cookers boil the fish in an enclosed process } \\
\text { - lixuid from solid fraction } \\
\text { - Conveyed to dryers at high temperatures } \\
\text { - Passes through hammer mills forming finer particles } \\
\text { - Hine powder blown onto hopper using industrial fans } \\
\text { - Hinto Hessian bags (semi-automated) } \\
\text { - Spilled fishmeal manually swept, shovelled, and tipped into bags }\end{array}$ & $\begin{array}{l}\text { - Inhalation of formalin, hydrogen } \\
\text { sulphide gas from decomposing fish in } \\
\text { pits } \\
\text { - Inhalation of dry dust aerosols during } \\
\text { fishmeal bagging }\end{array}$ \\
\hline
\end{tabular}

the proteinacious fish material causes a chronic recurrent dermatitis commonly known as protein contact dermatitis (PCD). At least $75 \%$ of eczematous dermatitis cases are however of an irritant nature due to contact with water and products in fish juice. ${ }^{8}$ Other che- mical agents (hand cleaners, soaps, detergents) used by workers also cause an irritant contact dermatitis. Biochemical sensitisers (for example, garlic, onion, spices, mustard) added to seafood produce a delayed allergic contact dermatitis.

\section{Measures to protect workers}

Primary preventive measures are key to minimising exposure to workplace hazards that result in occupational injuries or diseases. These include surveillance of exposures, injuries, and diseases; analysis of surveillance data to

Table 2 Commonly observed hazards, causative agents, and associated health effects in the fish processing industry

\begin{tabular}{|c|c|c|}
\hline Hazard category & Causative agents/processes & Health effect(s) \\
\hline Safety & $\begin{array}{l}\text { Unprotected machinery } \\
\text { Wet surfaces causing slips and falls } \\
\text { Electrical cables on wet surfaces } \\
\text { Splashing of fish secretions (bile) }\end{array}$ & $\begin{array}{l}\text { Hand trauma (cuts, lacerations, calluses) } \\
\text { Sprains and fractures } \\
\text { Electrocution } \\
\text { Corneal erosions }\end{array}$ \\
\hline Physical & $\begin{array}{l}\text { Noise (cannery) } \\
\text { Low temperatures (freezers) and wet environments }\end{array}$ & $\begin{array}{l}\text { Noise induced hearing loss } \\
\text { Hypothermia, frost-bite, Raynaud's, asthma aggravation }\end{array}$ \\
\hline Chemical & $\begin{array}{l}\text { Sensitisers (formalin, printing inks, glue) } \\
\text { Irritants (handcleaners, soaps, detergents) } \\
\text { Toxic gasses in fish holding tanks (hydrogen sulphide) } \\
\text { Hypertonic saline aerosols (sea water) }\end{array}$ & $\begin{array}{l}\text { Rhinoconjunctivitis, asthma, dermatitis } \\
\text { Dermatitis, rhinoconjunctivitis, asthma } \\
\text { Asphyxiation } \\
\text { Aggravation of asthma symptoms }\end{array}$ \\
\hline Biological & $\begin{array}{l}\text { Spiny fish } \\
\text { Fish toxins } \\
\text { Fish proteins (muscle, blood, enzymes) } \\
\text { Vegetable dust additives (garlic, spices) } \\
\text { Parasites (Anisakis) } \\
\text { Microorganisms (Vibrio, hepatitis A) } \\
\text { Bacterial toxins (endotoxin, histamine) } \\
\text { Mould in wet, damp, humid environments }\end{array}$ & $\begin{array}{l}\text { Hand trauma (puncture wounds, lacerations) } \\
\text { Toxic reactions (local/generalised) } \\
\text { Rhinoconjunctivitis, asthma, urticaria, dermatitis } \\
\text { Rhinoconjunctivitis, asthma, urticaria, dermatitis } \\
\text { Infection, rhinoconjunctivitis, asthma, urticaria } \\
\text { Wound infection, sepsis } \\
\text { Organic dust toxic syndrome, mucous membrane irritation, } \\
\text { rhinoconjunctivitis, asthma, urticaria } \\
\text { Infection, rhinoconjunctivitis, asthma, urticaria, hypersensitivity } \\
\text { pneumonitis }\end{array}$ \\
\hline Ergonomic & $\begin{array}{l}\text { Repetitive work (cutting and trimming of fillets), forceful motions } \\
\text { of upper limbs, constrained neck postures (sorting), prolonged } \\
\text { standing (grading, sorting), loading bags and cans }\end{array}$ & $\begin{array}{l}\text { Musculoskeletal cumulative trauma disorders (neck pain, shoulder } \\
\text { girdle pain, elbow pain/epicondylitis, wrist pain/carpal tunnel } \\
\text { syndrome, lower backache) }\end{array}$ \\
\hline Psychosocial & Excessive speed on workline, poor workplace organisation & $\begin{array}{l}\text { Stress related symptoms (anxiety, insomnia, digestive problems), } \\
\text { fatigue }\end{array}$ \\
\hline
\end{tabular}




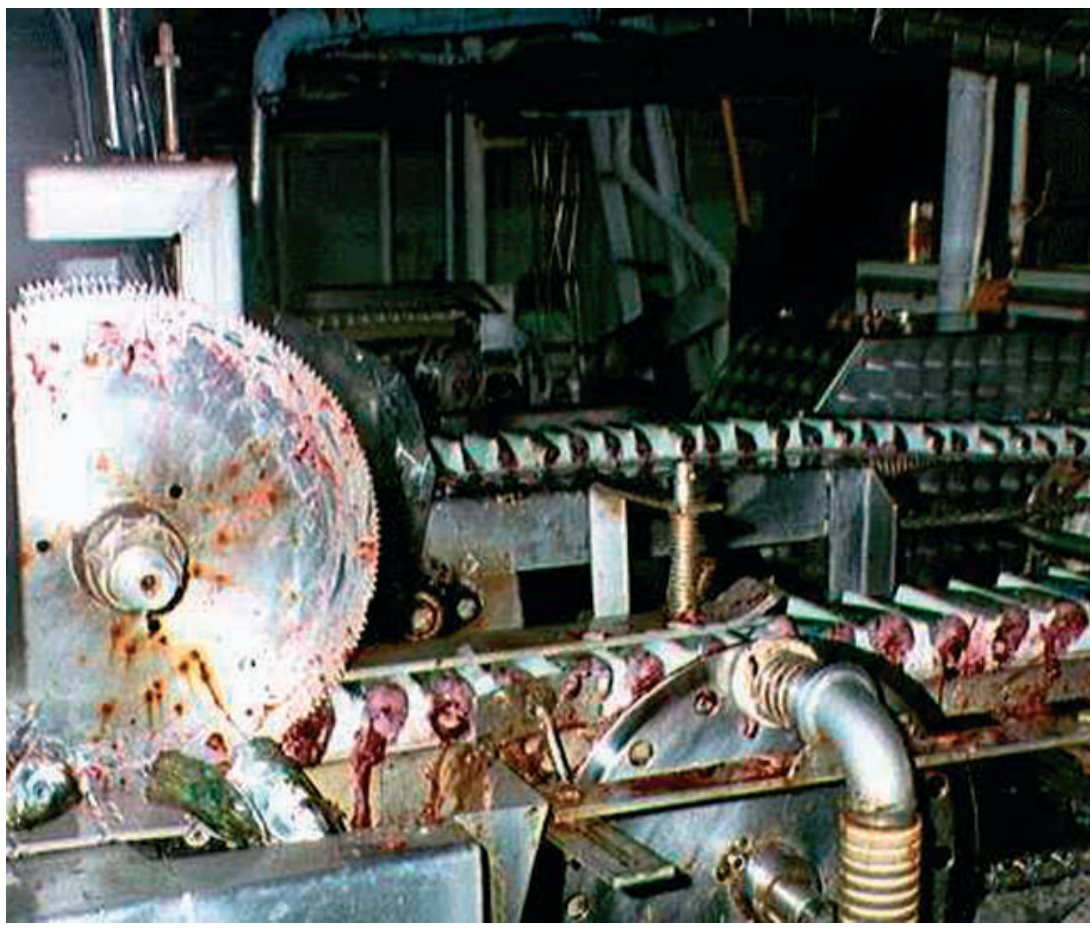

Figure 1 Degutting and heading of pilchard generating bioaerosols and safety hazards in the cannery. Enclosure of the autopacker machine will substantially reduce health risks.

assess risk and identify trends; control of workplace hazards through engineering controls, personal protective equipment, and administrative procedures; and education and training programmes for workers to ensure adequate precautions. ${ }^{14}$

The control of exposure to physical hazards such as excessive noise and cold temperature is standard to any type of industry. Primary preventive measures

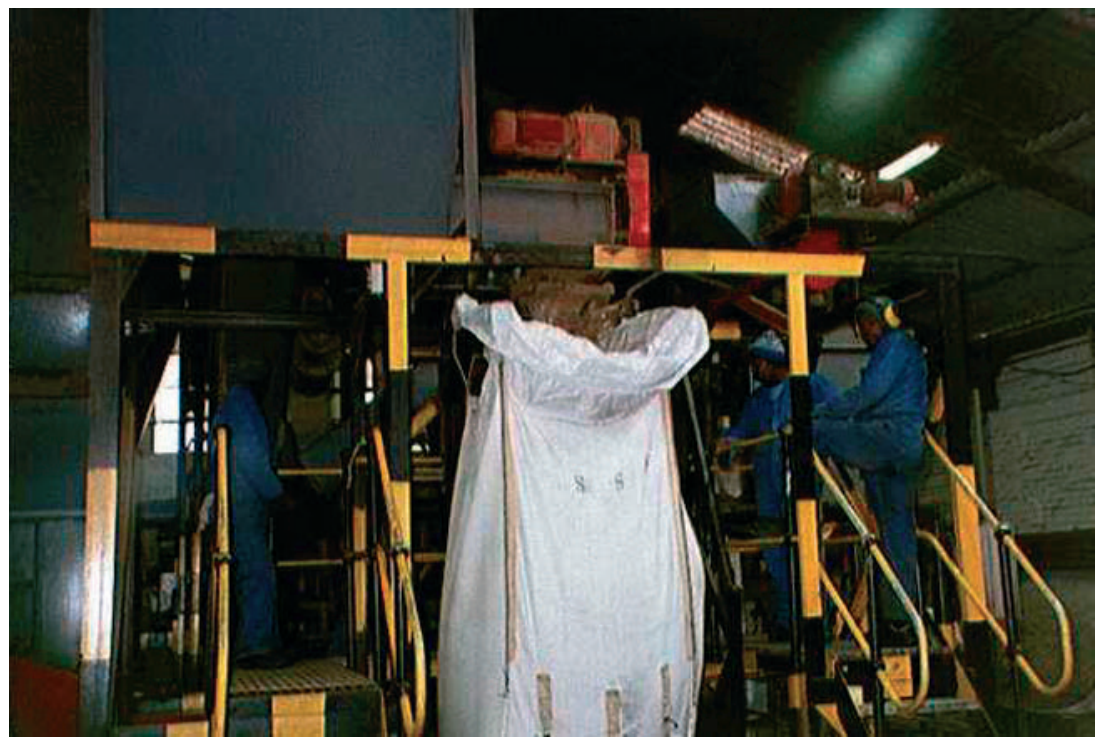

Figure 2 Bagging of fishmeal causes spillage and aerosolised dust particulate if inadequately removed by local exhaust ventilation systems. Hearing protectors are worn by some workers. Mechanical hoisting of bags prevents ergonomic hazards. hearing loss (fig 2)..$^{15}$ Reducing health risks associated with cold temperatures exacerbated by wet conditions include: limiting duration of exposure in refrigeration sections; wearing of adequate insulating clothing and personal protective equipment (gloves, boots); adequate rest periods in dry and warm air-conditioned restrooms; and sufficient nutrition and warm beverages.

South African regulatory standards for bioaerosols are based on the well known European directive no. 2000/54/ EC dealing with the protection of workers from risks related to exposure to biological agents at work. ${ }^{14}{ }^{16}$ The health risks associated with exposure to biological agents (microbial agents, allergens, and toxins) depend on the degree of pathogenicity or toxicity of the agent, the route of transmission, and the level of exposure to the agent. Control measures to reduce the emission of bioaerosols in fish processing plants include process separation or enclosure and the use of local extraction ventilation systems to processes and equipment (gutting machine, fishmeal bagging) (figs 1 and 2). Fitting a local exhaust ventilation system in a salmon processing plant reduced the overall mean respirable aerosol concentration from $2.37 \mathrm{mg} / \mathrm{m}^{3}$ to less than $0.01 \mathrm{mg} / \mathrm{m}^{3} .{ }^{11}$ This resulted in no new cases of occupational asthma over a 24 month period versus an initial $8 \%$ prevalence prior to the intervention. Where there is skin contact with the hazardous agent (fish sorting, spice mixing), appropriate gloves (cotton lined) and plastic sleeves can be worn (fig 3). Puncture wounds and lacerations should be treated expeditiously to prevent infection and skin exposure to allergens in fish juice. An appropriate combination of emollients and moisturisers can be used prophylactically to protect skin barrier function and prevent the development of irritant contact dermatitis. ${ }^{8}$ Special care should be taken when instituting preventive measures that one hazard is not replaced by another, such as using latex gloves and inadvertently causing latex allergy.

Exposure monitoring for bioaerosols (for example, bacterial/spore counts, endotoxin or allergen levels) can evaluate the effectiveness of control measures in decreasing the risk of infection and/or allergic sensitisation of other, as yet unaffected, workers. Medical surveillance programmes can be used as a useful adjunct to industrial hygiene evaluation and control measures. Various early subclinical biomarkers (for example, serum eosinophilic cationic protein, skin prick testing with fish extracts, fish specific serum IgE or IgG antibodies) and target organ tests (for 


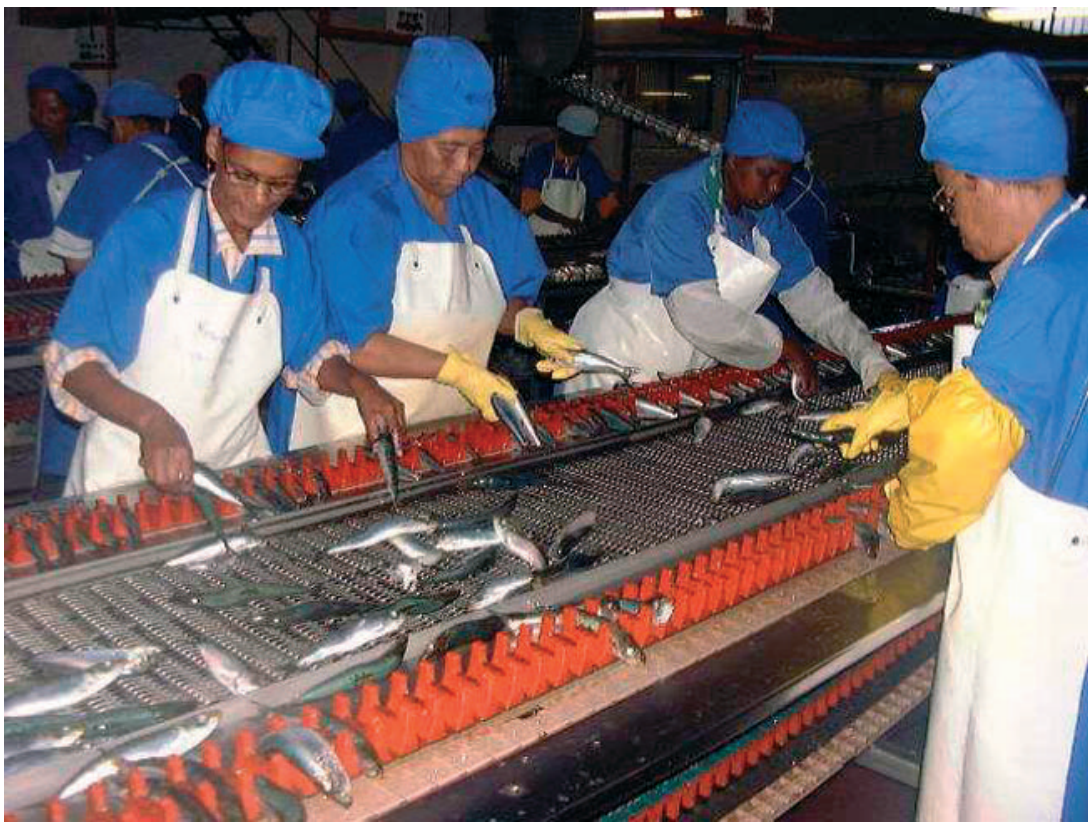

Figure 3 Fish sorting activities generate ergonomic hazards due to high conveyor belt speed, repetitive work, prolonged standing, and abnormal postures. Unprotected handling of fish results in irritant contact dermatitis and urticaria.

example, non-specific bronchial hyperresponsiveness, skin patch tests with fresh fish) can be used to detect early inflammation, allergic sensitisation, or adverse health outcomes such as asthma, extrinsic allergic alveolitis, or contact dermatitis among affected workers. ${ }^{214}$

Improvements in workplace design, such as introduction of conveyor belts for transporting fish at reasonable speeds; adjustable tables and platforms to stand on; adjustable sit/stand stools; provision of foot rests; and anti-fatigue mats have an important role in dealing with ergonomic hazards (fig 3). ${ }^{17-19}$ In situations where personal protective equipment is indicated, proper fitting gloves should be provided so as to reduce the hand and finger force required to perform a repetitive task. Aside from ensuring appropriate design of hand tools, workers should be educated in maintaining a neutral wrist when performing repetitive motions in the fish filleting and sorting departments. In the bagging and packing departments, the use of mechanical lifts for loading cans and fishmeal bags and training on correct lifting techniques will alleviate back stress and prevent injury (fig 2). Improved workplace organisation, including the formation of joint health and safety committees, participatory management styles, well defined organisational philosophies on occupational health and safety, modified work provision post-injury at work, job rotation, and recognition of other local pyschosocial stress factors (for example, gender roles, seasonal work, low income) will have an impact in reducing work related stress and cumulative trauma disorders among fish processing workers. ${ }^{30}$

\section{ACKNOWLEDGEMENTS}

We would like to thank Noah Seixas from the Department of Environmental Health at the University of Washington; Mary Miller from the Washington State Department of Labour and Industries; Madimetja Molekwa from the Occupational and Environmental Health Research Unit (UCT); Raymond Beukes, Simphiwe Mbuli, and Emmanuel Rusford from Pensinsula Technikon; and Joshua Fernandez, Gerald Reese, and Samuel Lehrer from Tulane Medical Centre for their assistance with various aspects of the project. This publication was supported by research grants from the Medical Research Council of South Africa and R01 Grant No. F002304 from NIOSH, CDC, USA. Its contents are solely the responsibility of the authors and do not necessarily reflect the official views of these agencies.

Occup Environ Med 2004;61:471-474. doi: 10.1136/oem.2002.001099

\section{Authors' affiliations}

\section{F Jeebhay, Occupational and}

Environmental Health Research Unit, School of Public Health and Family Medicine, University of Cape Town, South Africa

T G Robins, Department of Environmental Health Sciences, University of Michigan, USA A L Lopata, Allergology Unit, Department of Immunology, Groote Schuur Hospital, Cape Town, South Africa
Correspondence to: $\operatorname{Dr} M \mathrm{~F}$ Jeebhay, Occupational and Environmental Health Research Unit, School of Public Health and Family Medicine, University of Cape Town, Room 4.44, Fourth Level, Falmouth Building, Anzio Road, Observatory, 7925, South Africa; mieebhay@cormack.uct.ac.za

\section{REFERENCES}

International Labour Organisation. Safety and health in the fishing industry. Geneva: ILO, 1999.

2 Jeebhay MF, Robins TG, Lehrer SB, et al. Occupational seafood allergy-a review. Occup Environ Med 2001;58:553-62.

3 Messing K, Reveret J-P. Are women in female jobs for their health? A study of working conditions and health effects in the fish-processing industry in Quebec. Int J Health Serv 1983; 13:635-48.

4 Nordander C, Ohlsson K, Balogh I, et al. Fish processing work: the impact of two sex dependent exposure profiles on musculoskeletal health. Occup Environ Med 1999:56:256-64.

5 Jeebhay MF, Lopata AL, Robins TG. Seafood processing in South Africa-a study of working practices, occupational health services and allergic health problems in the industry. Occup Med 2000:50:406-13.

6 Conway GA, Husberg B. Cold-related non-fata injuries in Alaska. Am J Ind Med 1999;(suppl 1):39-44.

7 Durborow RM. Health and safety concerns in fisheries and aquaculture. Occup Med 1999; 14:373-406

8 Halkier-Sorensen L. Occupational skin diseases. Contact Dermatitis 1996;35(1 suppl): 1-120.

Chiang HC, Ko YC, Chen SS, et al. Prevalence of shoulder and upper-limb disorders among workers in the fish-processing industry. Scand J Work Environ Health 1993;19:126-31.

10 Ohlsson K, Hansson GA, Balogh I, et al. Disorders of the neck and upper limbs in women in the fish processing industry. Occup Environ Med 1994;51:826-32

11 Douglas JDM, Mc Sharry C, Blaikie L, et al. Occupational asthma caused by automated salmon processing. Lancet 1995;346:737-40.

12 Taylor AV, Swanson MC, Jones RT, et al. Detection and quantitation of raw fish aeroallergens from an open-air fish market. J Allergy Clin Immunol 2000;105:166-9.

13 Dutch Expert Committee on Occupational Standards (DECOS). Endotoxins: health-based recommended exposure limit. A report of the Health Council of the Netherlands. Publication no. 1998;03WG:1-15.

14 Jeebhay MF. An approach to hazardous biological agents in the workplace-legal provisions and practical considerations. Occupational Health Southern Africa 2002;8(2):8-13

15 Verma DK, Purdham JT, Roels HA. Translating evidence about occupational conditions into strategies for prevention. Occup Environ Med 2002;59:205-13.

16 European Parliament. Directive 2000/54/EC. The protection of workers from risks related to exposure to biological agents at work. Official Journal L 262, 2000;0021-0045 (http:// www.allriskmgmt.co.uk/directives/00-054.htm).

17 Fairfax R. Ergonomic hazards in the fish processing industry: Part I. Appl Occup Environ Hyg 1997; 12:245-9.

18 Golias E, Motley K, Fairfax R. Ergonomic hazards in the fish processing industry: Part II. Appl Occup Environ Hyg 1997; 12:329-35.

19 Golias E, Fairfax R. Ergonomic hazards in the fish processing industry: Part III. Appl Occup Environ Hyg 1997; 12:400-6.

20 Shannon HS, Robson LS, Sale JE. Creating safer and healthier workplaces: role of organizational factors and job characteristics. Am J Ind Med 2001;40:319-34. 